\title{
Endometrial local injury, a simple procedure that improves IVF outcome in a selected
} population of patients

\author{
Irit Granot* and Nava Dekel
}

Department of Biological Regulation, The Weizmann Institute of Science, Rehovot, Israel

Received: 15 September, 2020
Accepted: 22 September, 2020
Published: 24 September, 2020

*Corresponding author: Irit Granot, Department of Biological Regulation, The Weizmann Institute of Science, Rehovot, Israel. Tel: +972546279289; Fax: +89282536; E-mail: granotirit@gmail.com

https://www.peertechz.com

Check for updates
Embryo implantation, an essential prelude for the establishment of pregnancy, is successful upon the interaction of a high-quality embryo with a receptive uterus. Nevertheless, 'inadequate uterine receptivity' which has been pointed out as the cause for approximately two-thirds of repeated implantation failures (RIF, [1-3]), combined with the low rate of implantation $(\sim 25 \%)$ obtained upon transfer of good embryos in IVF, makes implantation the rate-limiting step for the success of ART.

Joining the pressing need to deepen the knowledge on implantation and to define biological markers for predicting implantation competence, we studied the expression profile of the gap junction protein in the uterus throughout the menstrual cycle [4]. For this purpose, repetitive endometrial sampling (biopsies) was performed during the spontaneous menstrual cycles of 12 IVF patients who had undergone several failing cycles of treatment. Surprisingly, 11 of these patients conceived at the following IVF cycle. Further exploration of this phenomenon in a larger group of patients, indeed showed for the first time, that repeated endometrial biopsy substantially increased the IVF outcome in RIF patients [5]. This favorable effect of endometrial biopsy on IVF outcome, was later demonstrated by other clinical centers, most of which selected RIF patients undergoing IVF for their studies [6-13].

Other studies challenged these findings, claiming that endometrial injury does not improve IVF outcome. Yeung, et al. [14] however, did not test a homogeneous population of IVF patients with RIF. Even more concerning was the fact that participants in this study as well as in the study by Liu, et al. [15] were subjected, prior to the endometrial biopsy, to either Saline Infusion Sonogram (SIS) or hysteroscopy. These procedures, on their own, could cause mechanical injury that may positively affect endometrial receptivity, leaving no potential for beneficial effect of the biopsy.

The most significant study on this topic was published by Lensen, et al. in NEJM [16], concluding that "Endometrial scratching did not result in a higher rate of live-birth than no intervention among women undergoing IVF." Moreover, these authors stated that "endometrial scratch should no longer be offered". This conclusion is indeed based on a pragmatic, multicenter, open-label, randomized, controlled trial of a total of 1364 IVF patients. An impressive sample size indeed! Nevertheless, examining the data we learn that $87.9 \%$ of the control group and $88.2 \%$ of the experimental group are not defined as RIF patients. This analysis of nonselected patients is somewhat surprising as the first author of this paper coauthors a Cochrane review published by Nastri, et al. in 2015 [17], anticipating that the effect of mechanical uterine intervention might differ between women in whom implantation had failed repeatedly and women in whom it had not. To confront this point, the current study updated the previously made calculation, to reach a size which keeps the study power adequate and allows the detection of betweengroup differences in live-birth rates of $15 \%$. Nevertheless, this size amendment still leaves secondary factors defining subgroups not randomized. In the absence of randomization, these factors may correlate with other covariates potentially influencing the treatment effect among subgroups. Another major limitation of this study is the lack of an identical protocol for all participating clinics, obviously expected from a multicenter study. The timing of the endometrial biopsy varied greatly among the different clinics, spreading over a month, between day 3 of the preceding cycle and day 3 of the 
cycle of treatment. Most importantly, there was no common protocol for the timing of ET that is well known to directly affect IVF outcome. Embryos selected for transfer ranged throughout different developmental stages. The knowledge that blastocysts make a selected, top quality population, with higher implantation potential than that of earlier cleavagestage embryos is commonly accepted. This fact, is not reflected in the analysis.

A more recent prospective multi-center randomized controlled study by Olesen, et al. [18], did apply a similar protocol for all participating clinics, in which biopsy was performed during the luteal phase, day 18-22 of the preceding cycle to the IVF treatment. Moreover, the effect of the biopsy was tested on different homogeneous subgroups of IVF patients, showing that "endometrial scratching in the luteal phase before ovarian stimulation significantly improves the IVF outcome in patients with three or more prior implantation failures".

Joining this continuing debate, and attempting to reach a conclusion, several Meta- analyses were performed using the data of the different randomized controlled trials (RCTs). Despite the large variability among the different RCTs in terms of the number and the timing of the biopsies, as well as the number of previous failing cycles of the IVF patients, a positive effect of endometrial biopsy on the rates of implantation, clinical pregnancies and life births could be demonstrated. Cochrane analysis by Nastri, et al. [17] as well as by Vitagliano, et al. [19], revealed that endometrial injury is associated with an improvement in live birth and clinical pregnancy rates in women with more than two previous failing embryo transfers. Sar-Shalom, et al. [20] showed that endometrial injury during the luteal phase of the preceding cycle, improved IVF success in younger patients (age $\leq 30$ years) who had undergone no more than two previous failing cycles, whereas, in the older group, in whom quality of embryos is lower, the effect was not significant.

The fact that the immune system plays a central role in implantation is commonly accepted [21-30]. In full agreement with this knowledge, basic science experiments provided clear evidence that the mechanism by which local injury stimulates the endometrium to increase its receptivity for implantation, involves the immune system, which responds in a 'wound healing-like' manner. Specifically, endometrial biopsy performed during the proliferative phase of the spontaneous menstrual cycle, increases the expression of pro-inflammatory cytokines that in turn recruit macrophages and DCs to the inflammation site. These immune cells secrete cytokines and growth factors that enhance the inflammatory reaction, triggering the endometrial epithelium to produce molecules, such as integrins and OPN facilitating implantation [3032]. Later studies demonstrated a direct correlation between the expression of these molecules in the endometrium of IVF patients and IVF outcome [33]. Furthermore, it has been recently reported that endometrial scratching is a recommended protocol for the enhancement of endometrial receptivity in patients with low immune activation [34]. These inflammatory events apparently do not take place in RIF patients in the absence of mechanical intervention.
As reported in all of the above-mentioned studies, endometrial injury is performed with a biopsy 'Pipelle' catheter. This procedure that for some reason, gained the definition of 'endometrial scratching', is a simple, almost harmless procedure that has been used for many years for diagnosis of endometrial pathologies and for endometrial dating, such as the ERA test [35].

Taken together, it is strongly suggested that any clinical recommendation taken should await a multi-center controlled randomized trial of endometrial injury performed using one identical protocol of treatment on a selected group of IVF patients to whom embryos of a single specific developmental stage are transferred. Conclusions made otherwise may be premature, not benefiting, but rather harming IVF patients.

\section{References}

1. Edwards RG (1994) Hum Reprod 9: 985-995.

2. Simon C, Moreno C, Remohi J, Pellicer A (1998) Molecular interactions between embryo and uterus in the adhesion phase of human implantation. Hum Reprod 13: 219-232. Link: https://bit.ly/3iUDvK2

3. Fatemi HM, Popovic-Todorovic B (2013) Implantation in assisted reproduction: a look at endometrial receptivity. Reprod Biomed Online 27: 530-538. Link: https://bit.ly/3cxtKPT

4. Granot I, Dekel N, Bechor E, Segal I, Fieldust S, et al. (2000) Fertil Sterilt 73 381-386.

5. Barash A, Dekel N, Fieldust S, Segal I, Schechtman E, Granot I. et al. (2003) Local injury to the endometrium doubles the incidence of successful pregnancies in patients undergoing in vitro fertilization. Fertil Steril 79: 13171322. Link: https://bit.ly/301xgNb

6. Raziel A, Schachter M, Strassburger D, Berno O, Ron-El R, et al. (2007) Favorable influence of local injury to the endometrium in intracytoplasmic sperm injection patients with high-order implantation failure. Fertil Steril 87 198-201. Link: https://bit.ly/2FZC66B

7. Nossair WS, El Behery MM, Al S, Farag M (2014) Open J Obstet Gynecol 4: 217-227.

8. Zhou L, LiR, Wang R, Huang H-X, Zhong K (2008) Local injury to the endometrium in controlled ovarian hyperstimulation cycles improves implantation rates. Fertil Steril 89: 1166-1176. Link: https://bit.ly/2ROPrBb

9. Karimzadeh MA, Ayazi Rozbahani M, Tabib Jad N (2009) Aust \& N Z J Obstet \& Gynecol 49: 677-680.

10. Narvekar SA, Gupta N, Shetty N, Kottur A, Srinivas MS, et al. Does local endometrial injury in the nontransfer cycle improve the IVF-ET outcome in the subsequent cycle in patients with previous unsuccessful IVF? A randomized controlled pilot study. J Hum Reprod Sci 3: 15-19. Link: https://bit.ly/3mG5xeF

11. Nastri CO, Ferriani RA, Raine-Fenning N, Martins WP (2013) Endometria scratching performed in the non-transfer cycle and outcome of assisted reproduction: a randomized controlled trial. Ultrasound Obstet Gynecol 42 375-382. Link: https://bit.ly/35STFjA

12. Guven S, Kart C, Unsal MA, Yildirim O, Odaci E, et al. (2013) Endometrial injury may increase the clinical pregnancy rate in normoresponders undergoing long agonist protocol ICSI cycles with single embryo transfer. Eur J Obstet Gyn \& Reprod Biol 173: 58-62. Link: https://bit.ly/2RQBKSd

13. Maged AM, Rashwan H, AbdelAziz S, Ramadan W, Mostafa WAl, et al. (2017) Randomized controlled trial of the effect of endometrial injury on implantation and clinical pregnancy rates during the first ICSI cycle. Int J Gynecol Obstet 140: 211-216. Link: https://bit.ly/2RQQzEm 
14. Yeung TWY, Chai J, Wun Li RH, Lee YLV, Ho PC, et al. (2014) Hum Reprod 29 2474-2481.

15. Liu W, Reshef T, Chao H, Liu M, Liu Y (2017) Reprod Biol Endocrinol 15: 75-81.

16. Lensen S, Osavlyuk D, Armstrong S, Stadelmann C, Hennes A, et al. (2019) A Randomized Trial of Endometrial Scratching before In Vitro Fertilization. NEJM 380: 325-334. Link: https://bit.ly/32QzctB

17. Nastri CO, Lensen SF, Gibreel A, Raine-Fenning N, Ferriani RA, et al. (2015) Endometrial injury in women undergoing assisted reproductive techniques. Cochrane Database Syst Rev CD009517. Link: https://bit.ly/2HoxJTd

18. Olesen M, Hauge B, Ohrt L, Olesen TN, Roskær J, et al. (2019) Therapeutic endometrial scratching and implantation after in vitro fertilization: a multicenter randomized controlled trial. Fertil Steril 112: 1015-1021. Link: https://bit.ly/2FWOqGu

19. Vitagliano A, Sardo ADS, Saccone G, Valenti G, Sapia F, et al. (2018) Endometrial scratch injury for women with one or more previous failed embryo transfers: a systematic review and meta-analysis of randomized controlled trials. Fertil Steril 110: 687-702. Link: https://bit.ly/32Qebil

20. Sar-Shalom NC, Sagi-Dain L, Wiener-Megnazi Z, Dirnfeld M (2019) The impact of intentional endometrial injury on reproductive outcomes: a systematic review and meta-analysis. Hum Reprod Update 25: 95-113. Link: https://bit.ly/35ZiFWw

21. Robertson SA (2000) Control of the immunological environment of the uterus. Rev Reprod 5: 164-174. Link: https://bit.ly/2FRjvcX

22. Croy BA, He H, Esadeg S, Wei Q, McCartney D, et al. (2003) Uterine natural killer cells: insights into their cellular and molecular biology from mouse modelling Reproduction 126: 149-160. Link: https://bit.ly/35XWC2r

23. Kopcow HD, Allan DS, Chen X, Rybalov B, Andzelm MM, et al. (2005) Human decidual NK cells form immature activating synapses and are not cytotoxic. Proc Natl Acad Sci U S A 102: 15563-15568. Link: https://bit.ly/3ckgq0Q

24. Verma S, Hiby SE, Loke YW, King A (2000) Human decidual natural killer cells express the receptor for and respond to the cytokine interleukin 15. Biol Reprod 62: 959-968. Link: https://bit.ly/2HmRRoO

25. Manaster I, Mizrahi S, Goldman-Wohl D, Sela HY, Stern-Ginossar N, et al
(2008) Endometrial NK cells are special immature cells that await pregnancy. J Immunol 181: 1869-1876. Link: https://bit.ly/3mIPdtO

26. Co EC, Gormley M, Kapidzic M, Rosen DB, Scott MA, et al. (2013) Maternal decidual macrophages inhibit NK cell killing of invasive cytotrophoblasts during human pregnancy. Biol Reprod 88: 155. Link: https://bit.ly/3cmAOyH

27. Kämmerer U (2005) Antigen-presenting cells in the decidua. Chem Immuno Allergy 89: 96-104. Link: https://bit.ly/3cnFwvZ

28. Rieger L, Honig A, Sütterlin M, Kapp M, Dieti J, et al. (2004) Antigen-presenting cells in human endometrium during the menstrual cycle compared to early pregnancy. J Soc Gynecol Investig 11: 488-493. Link: https://bit.ly/3mIOR6s

29. Thiruchelvam U, Dransfield I, Saunders PT, Critchley HO (2013) The importance of the macrophage within the human endometrium. J Leukoc Biol 93: 217-225. Link: https://bit.ly/3iVJPkx

30. Gnainsky Y, Dekel N, Irit Granot I (2014) Implantation: Mutual Activity of Sex Steroid Hormones and the Immune System Guarantee the Maternal-Embryo Interaction. Semin Reprod Med 32: 337-345. Link: https://bit.ly/3mGPr4s

31. Gnainsky Y, Irit Granot I, Aldo PB, Barash A, Or Y, et al. (2010) Local injury of the endometrium induces an inflammatory response that promotes successful implantation. Fertil Steril 94: 2030-2036. Link: https://bit.ly/3iSYa1l

32. Gnainsky Y, Granot I, Aldo P, Barash A, Or Y, et al. (2015) Biopsy-induced inflammatory conditions improve endometrial receptivity: the mechanism of action. Reproduction 149: 75-85. Link: https://bit.ly/33Kqe0o

33. Wang XB, Qi QR, Wu KL, Xie QZ (2018) Role of osteopontin in decidualization and pregnancy success. Reproduction 155: 423-432. Link: https://bit.ly/2FOHs4E

34. Lédée N, Petitbarat M, Prat-Ellenberg L, Dray G, Cassuto GN, et al. (2020) Endometrial Immune Profiling: A Method to Design Personalized Care in Assisted Reproductive Medicine. Front Immunol 11: 1032. Link: https://bit.ly/2FWMxHW

35. Ruiz-Alonso M, Blesa D, Díaz-Gimeno P, Gomez E, Fernandez-Sanchez M, et al. (2013) The endometrial receptivity array for diagnosis and personalized embryo transfer as a treatment for patients with repeated implantation failure. Fertil Steril 100: 818-824. Link: https://bit.ly/3cnErUX

\footnotetext{
Discover a bigger Impact and Visibility of your article publication with Peertechz Publications

Highlights

* Signatory publisher of ORCID

* Signatory Publisher of DORA (San Francisco Declaration on Research Assessment)

* Articles archived in worlds' renowned service providers such as Portico, CNKI, AGRIS, TDNet, Base (Bielefeld University Library), CrossRef, Scilit, J-Gate etc.

* Journals indexed in ICMJE, SHERPA/ROMEO, Google Scholar etc.

* OAI-PMH (Open Archives Initiative Protocol for Metadata Harvesting)

* Dedicated Editorial Board for every journal

* Accurate and rapid peer-review process

* Increased citations of published articles through promotions

* Reduced timeline for article publication

Submit your articles and experience a new surge in publication services (https://www.peertechz.com/submission).
}

Peertechz journals wishes everlasting success in your every endeavours.

Copyright: @ 2020 Granot I, et al. This is an open-access article distributed under the terms of the Creative Commons Attribution License, which permits unrestricted use, distribution, and reproduction in any medium, provided the original author and source are credited.

Citation: Granot I, Dekel N (2020) Endometrial local injury, a simple procedure that improves IVF outcome in a selected population of patients. J Gynecol Res Obstet 6(3): 064-066. DOI: https://dx.doi.org/10.17352/jgro.000089 